УДК 159.9

doi: $10.15330 / p s \cdot 9 \cdot 1.35-44$

Зоряна Ковальчук

Львівський державний університет внутрішніх справ

zoriana01051974@i.ua

\title{
ВПЛИВ ОСОБИСТІСНИХ ВЛАСТИВОСТЕЙ НА ФОРМУВАННЯ ПРОФЕСІЙНОЇ ДЕФОРМАЦІЇ ПРАЦВВИКІВ РИЗИКОНЕБЕЗПЕЧНИХ ПРОФЕСІЙ
}

\begin{abstract}
У статті теоретично обтрунтовано та емпірично доведено вплив особистісних властивостей на формування професійної деформаџї працівників ризиконебезпечних професій, зокрема слідчих та оперуповноважених підрозділів начіональної полічії Украӥни. Зазначено, щзо професійно важливі якості у фахівия розвиваються під час тривалої професійної діяльності, а разом з тим працівник набуває й інших якостей, які деформують особистість. Отже, у прочесі професійного становлення відбувається і розвиток різноманітних професійних деструкиій. 3 метою виявлення деформаџійних прочесів працівників правоохоронних органів різних підрозділів та визначення шляхів їх профілактики авторка провела емпіричне дослідження, використавщи низку психодіагностичних методик, зокрема, «Визначення психічного вигорання» О. О. Рукавишнікова, «Визначення інтегральних форм комунікативної агресивності» В. В. Бойка, «Вивчення інтегральних акцентуацій особистості» К. Леонгарда, модифікація С. Шмішека, «Особистісний опитувальник» Г. Айзенка, опитувальник «Професійне вигорання» (К. Маслач, С. Джексон, адаптовано Н. С. Водоп'яновою). Кореляційний аналіз показав, щзо у слідчих виявлено професійне «вигорання», пов'язане з психоемоційним виснаженням, особистісним віддаленням, професійною мотивацією, спонтанністю агресіі, екстраверсією-інтроверсією, редукцією персональних досягнень. В оперуповноважених професійне «вигорання» пов'язане з деперсоналізацією, екстраверсією-інтроверсією, невмінням переключати агресію на діяльність або неживі об'єкти, особистісним віддаленням, ритуалізацією агресії, аутоагресією та емоиійним виснаженням. Перспектива досліджень полягає у розробиі рекомендацій щзоо кадрового відбору на вищевказані професії з урахуванням особистісних властивостей претендентів на посади та профілактиці й використанні корекційних методів з метою зниження рівня професійного «вигорання» серед працівників поліцейських підрозділів та інших ризиконебезпечних професій.
\end{abstract}

Ключові слова: професійна деформація, професійне «вигорання», ризиконебезпечні професії, слідчі, оперуповноважені, емочійне виснаження.

Постановка проблеми. Професійно важливі якості у фахівця розвиваються під час тривалої професійної діяльності. Разом з тим працівник набуває й інших якостей, які деформують особистість. У процесі професійного становлення відбувається і розвиток різноманітних професійних деструкцій.

Вивченню професійної деформації присвятили свої наукові пошуки В. С. Медведсв, В. Я. Кікоть, Р.-В.В.Кісіль, Н. С. Афанасьєва, Д. Трунов), визначили компоненти синдрому «професійного вигорання» В. В Бойко, О. О. Рукавишніков, розглянули прояви професійної деформації працівників органів внутрішніх справ Н. П. Матюхіна, В. С. Олійников, Н. Є. Водоп'янова, Є. С. Старченкова та інші.

Однак теоретичні та емпіричні надбання у галузі знань, не досить повно розкривають психологічну сутність професійних деформацій та феномен професійного «вигорання», що, власне, і обмежує розуміння деформаційних процесів як руйнівного явища в сучасному суспільстві. Такий стан вивчення зазначеної проблеми вимагає психологічної розробки концепції деформаційних процесів особистості, всебічного дослідження цього явища в руслі сучасної психологічної науки.

Метою статті $\epsilon$ теоретично обгрунтувати та емпірично довести вплив особистісних властивостей працівників поліцейських підрозділів, робота яких є ризиконебезпечною, на формування в них професійної деформації.

Аналіз останніх публікацій. На думку 3. Р. Кісіль, під час професійного становлення особистість набуває не лише специфічні вміння та навички, але й особливе відчуття причетності до поглядів, шаблонів поведінки, цінностей, які характерні для носіїв певної професії [2, с. 165]. 
У зв’язку з тривалою професійною діяльністю працівники поліції починають настільки ототожнювати себе з професійними обов'язками, певними цінностями, шаблонами і таке інше, що втрачають відчуття тієї реальності, яка, власне, відмежовує функціонування здорової людини від деструктивних процесів. Така деструктивна «роль» стає «хронічною» у житті працівників поліції. Враховуючи також той факт, що необхідно часто діяти в умовах ризику, у вкрай екстремальних ситуаціях, фахівці правоохоронних органів упродовж тривалої професійної діяльності стають доволі підозрілими, дратівливими, надмірно обачливими, обережними, агресивними, більш жорстокими та 3 постійним відчуттям професійного обов'язку.

На переконання В. С. Медведєва, деформаційний процес поліцейських в сучасному суспільстві - це та ціна, яку особа сплачує за високий рівень мотивації, натхнення в контексті виконання професійно важливих завдань [4, с. 112].

Деформація поліцейських - феномен, який наносить неймовірної шкоди підрозділам поліції та назагал позбавляє повсякденної здорової діяльності осіб, які зазнали ії руйнівного впливу.

Враховуючи цей факт, О. Ю. Синявська стверджує, що є особливо динамічний процес надзвичайних екстремальних подій, які постійно трапляються у професії працівників поліції та внаслідок яких працівники дістають поранення або навіть наражаються на смерть [5, с. 98-99].

Виклад основного матеріалу. 3 метою виявлення деформаційних процесів працівників правоохоронних органів різних підрозділів та визначення шляхів їх профілактики, нами було проведено емпіричне дослідження у Пустомитівському районному відділі ГУНП України у Львівській області. Вибірка становила 80 працівників різних підрозділів, з них 35 слідчих та 45 оперуповноважених. 26 осіб працюють в правоохоронних органах 1 рік; 9 осіб - 3 роки; 5 осіб 5 років; 9 осіб - 7 років; 13 осіб - 10 років; 8 осіб - 15 років, 3 особи - 20 років та 7 осіб - 25 років служби в органах внутрішніх справ. Вік досліджуваних охоплював діапазон від 25 до 57 років.

При проведенні емпіричного дослідження використовувались наступні методики: «Визначення психічного вигорання» О. О. Рукавишнікова, «Визначення інтегральних форм комунікативної агресивності» В. В. Бойка, «Вивчення інтегральних акцентуацій особистості» К. Леонгарда, модифікація С. Шмішека, «Особистісний опитувальник» Г. Айзенка, опитувальник «Професійне вигорання» (К. Маслач, С. Джексон, адаптовано Н. Є. Водоп'яновою).

Припускаємо, що професійній деформації працівників внутрішніх справ передує емоційне вигорання та зумовлені ним особистісні властивості, а також деякі сталі характеристики особистості (психоемоційне виснаження, особистісне віддалення, професійна мотивація; агресивність; акцентуації характеру; екстра- та інтроверсія, нейротизм; тип темпераменту, емоційне виснаження, деперсоналізація та редукція персональних досягнень).

3 цією метою проведено кореляційний аналіз, результати якого описані нижче.

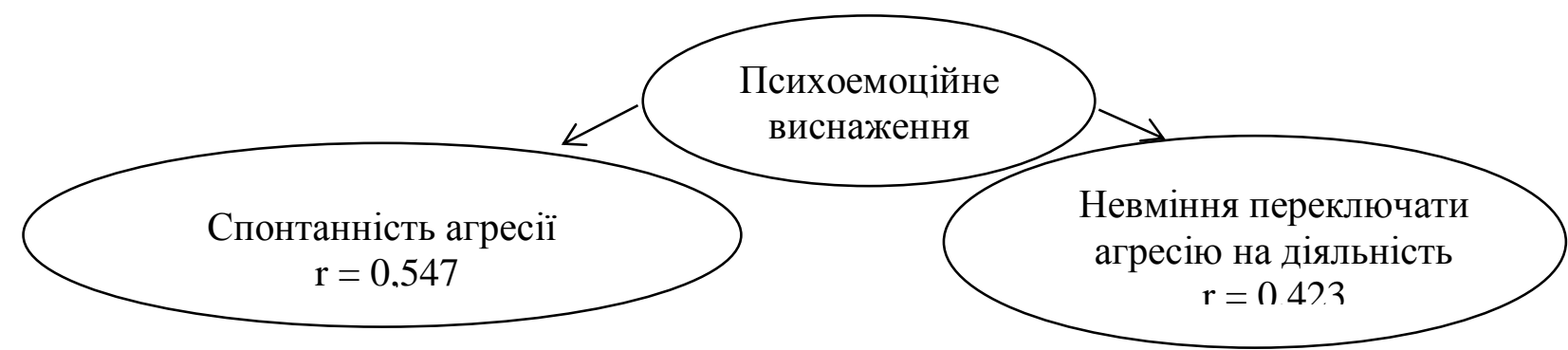

Puc. 1. Кореляційна плеяда психоемоційного виснаження, спонтанності агресії та невмінням переключати агресію на діяльність 
У слідчих виявлено прямий позитивний кореляційний зв'язок між психоемоційним виснаженням та спонтанністю агресії ( $\mathrm{r}=0,547 ; \mathrm{p}=0,05)$. При високих показниках психоемоційного виснаження показники спонтанності агресії теж були високими. Також був виявлений прямий позитивний кореляційний зв'язок поміж психоемоційним виснаженням та невмінням переключати агресію на діяльність або неживі об'єкти $(\mathrm{r}=0,423 ; \mathrm{p}=0,01)$. При високих показниках психоемоційного виснаження показники невміння переключати агресію на діяльність або неживі об'єкти були також високими.

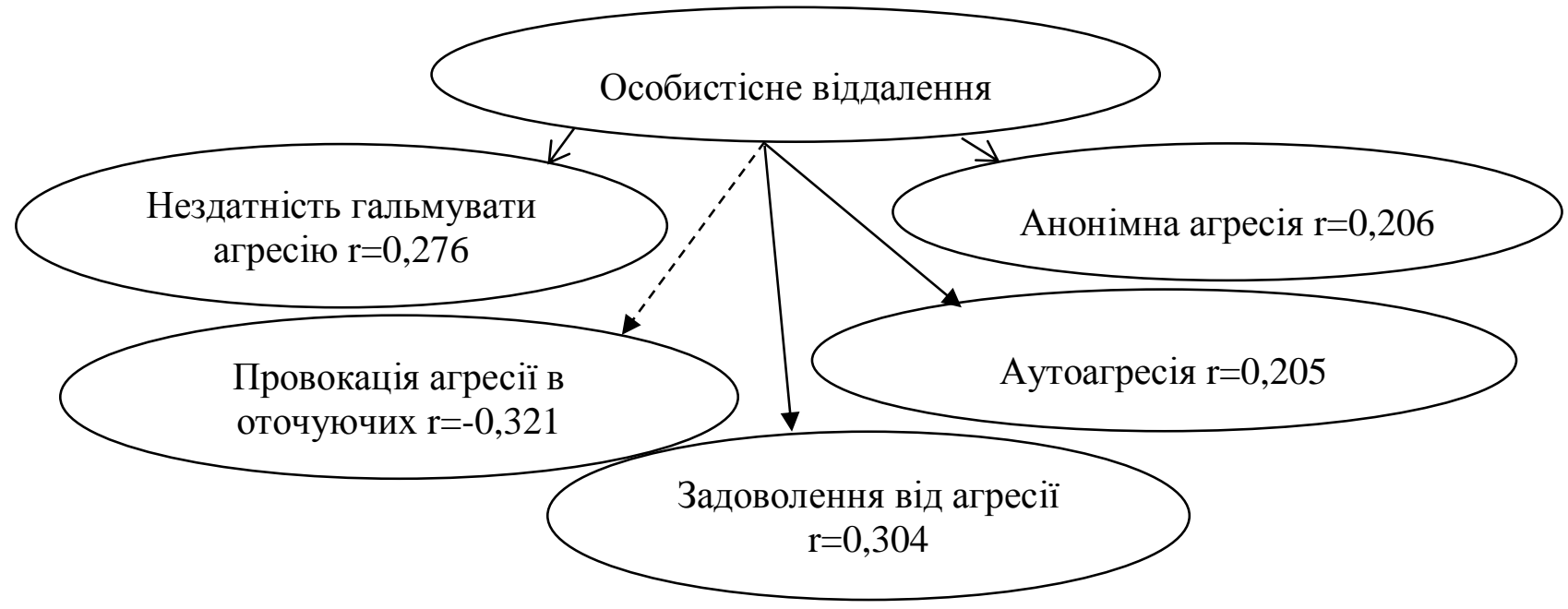

Puc. 2. Кореляційна плеяда особистісного віддалення, нездатності гальмувати агресію, анонімної агресії, провокації агресії в навколишніх, аутоагресії та задоволення від агресії

У слідчих виявлено прямий позитивний кореляційний зв'язок між особистісним віддаленням та нездатністю гальмувати агресію $(\mathrm{r}=0,276 ; \mathrm{p}=0,05)$; анонімною агресією ( $\mathrm{r}=0,206$; $\mathrm{p}=0,05)$; аутоагресією $(\mathrm{r}=0,205 ; \mathrm{p}=0,01)$ та задоволенням від агресії $(\mathrm{r}=0,304 ; \mathrm{p}=0,01)$. При високих показниках особистісного віддалення показники нездатності гальмувати агресію, анонімної агресії, аутоагресії та задоволення від агресії також були високими. Існував негативний обернений кореляційний зв'язок між особистісним віддаленням та провокацією агресії в навколишніх (r=-0,321; $\mathrm{p}=0,05)$. При високих показниках особистісного віддалення показники провокації агресії в навколишніх були низькими.

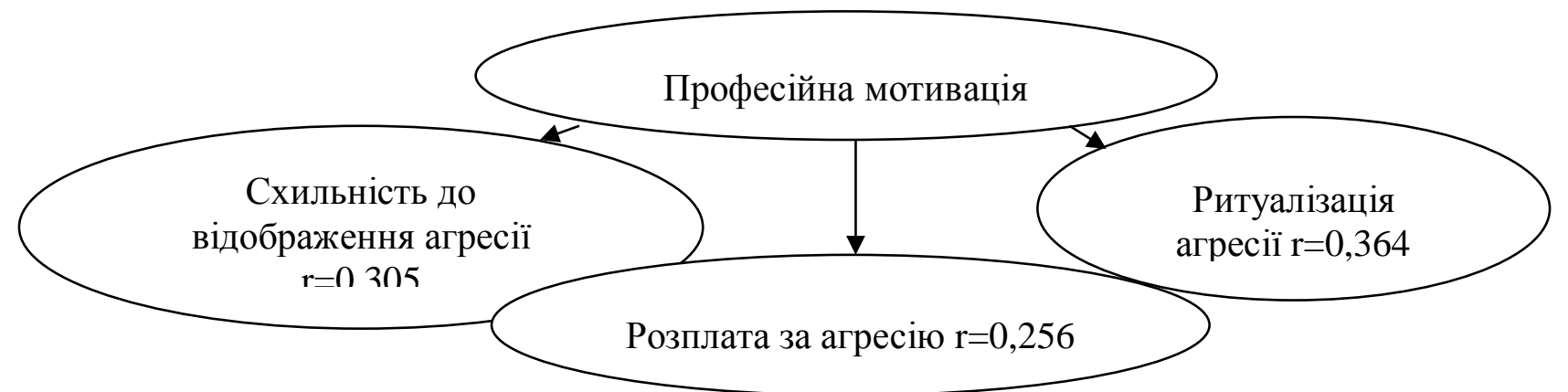

Рис. 3. Кореляційна плеяда професійної мотивації, схильності до відображення агресії, ритуалізація агресії та розплати за агресію

У слідчих виявлено прямий позитивний кореляційний зв'язок між професійною мотивацією та схильністю відображення агресії $(\mathrm{r}=0,305 ; \mathrm{p}=0,05)$; ритуалізацією агресії $(\mathrm{r}=0,364 ; \mathrm{p}=0,01)$ та розплатою за агресію $\quad(\mathrm{r}=0,256 ; \mathrm{p}=0,05)$. При високих показниках про- 
фесійної мотивації показники схильності до відображення агресії, ритуалізація агресії та розплати за агресію були також високими.

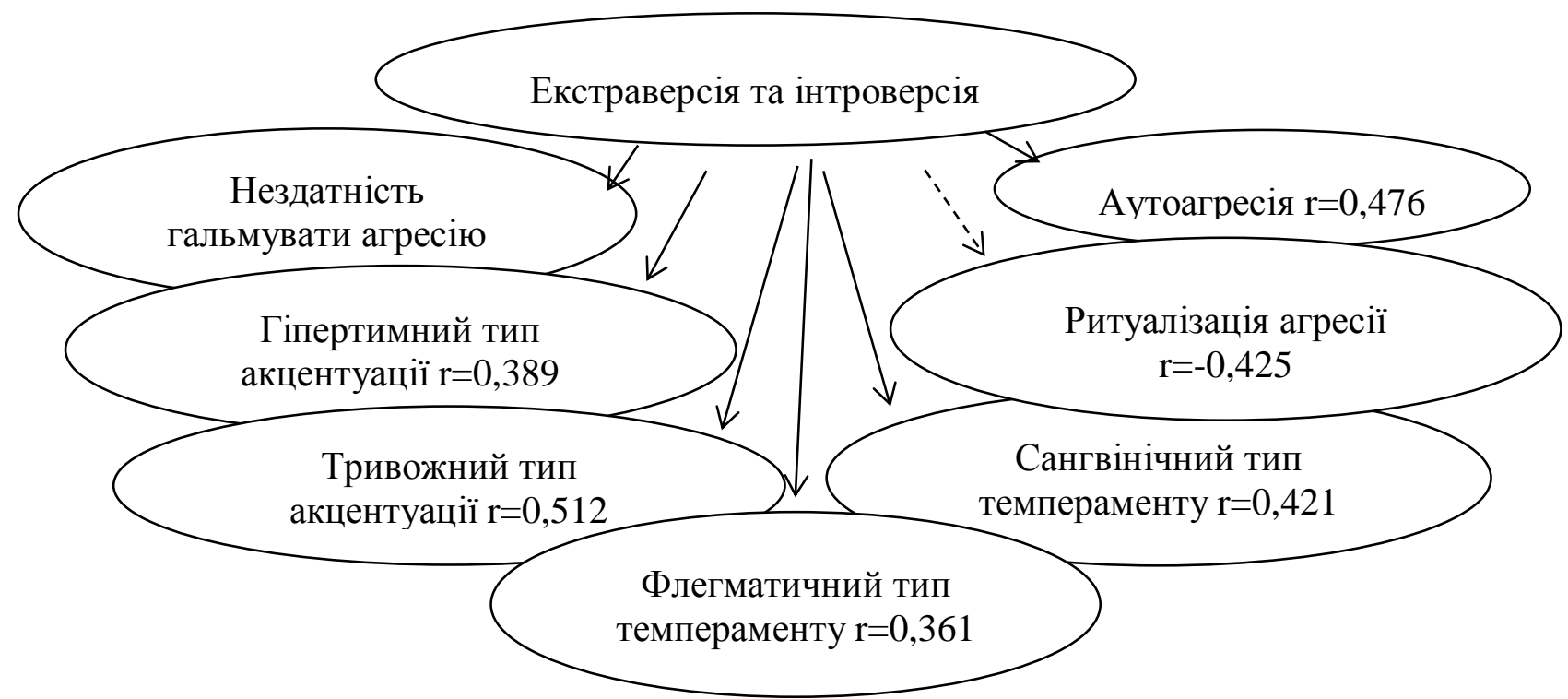

Puc. 4. Кореляційна плеяда екстраверсії та інтроверсії, нездатності гальмувати агресію, аутоагресії, ритуалізація агресії, гіпертимного та тривожного типів акцентуації характеру, сангвінічного та флегматичного типів темпераменту особистості

У слідчих виявлено прямий позитивний кореляційний зв'язок між екстраверсіюінтроверсією та нездатністю гальмувати агресію ( $\mathrm{p}=0,542 ; \mathrm{p}=0,05)$; аутоагресією $(\mathrm{r}=0,476$; $\mathrm{p}=0,01)$; гіпертимний типом акцентуації $(\mathrm{r}=0,389 ; \mathrm{p}=0,05)$; тривожним типом акцентуації $(\mathrm{r}=0,512 ; \mathrm{p}=0,01)$; сангвінічним типом темпераменту $(\mathrm{r}=0,421 ; \mathrm{p}=0,05)$ та флегматичним типом темпераменту (r=0,361; $\mathrm{p}=0,05)$. При високих показниках екстраверсії-інтроверсії показники нездатності гальмувати агресію, аутоагресії, гіпертимного та тривожного типів акцентуації характеру, сангвінічного та флегматичного типів темпераменту особистості також були високими. Існував негативний обернений кореляційний зв 'язок між екстраверсією-інтроверсією та ритуалізацією агресії $(-0,425 ; \mathrm{p}=0,01)$. При високих показниках екстраверсії-інтроверсії, показники ритуалізації агресії були низькими.

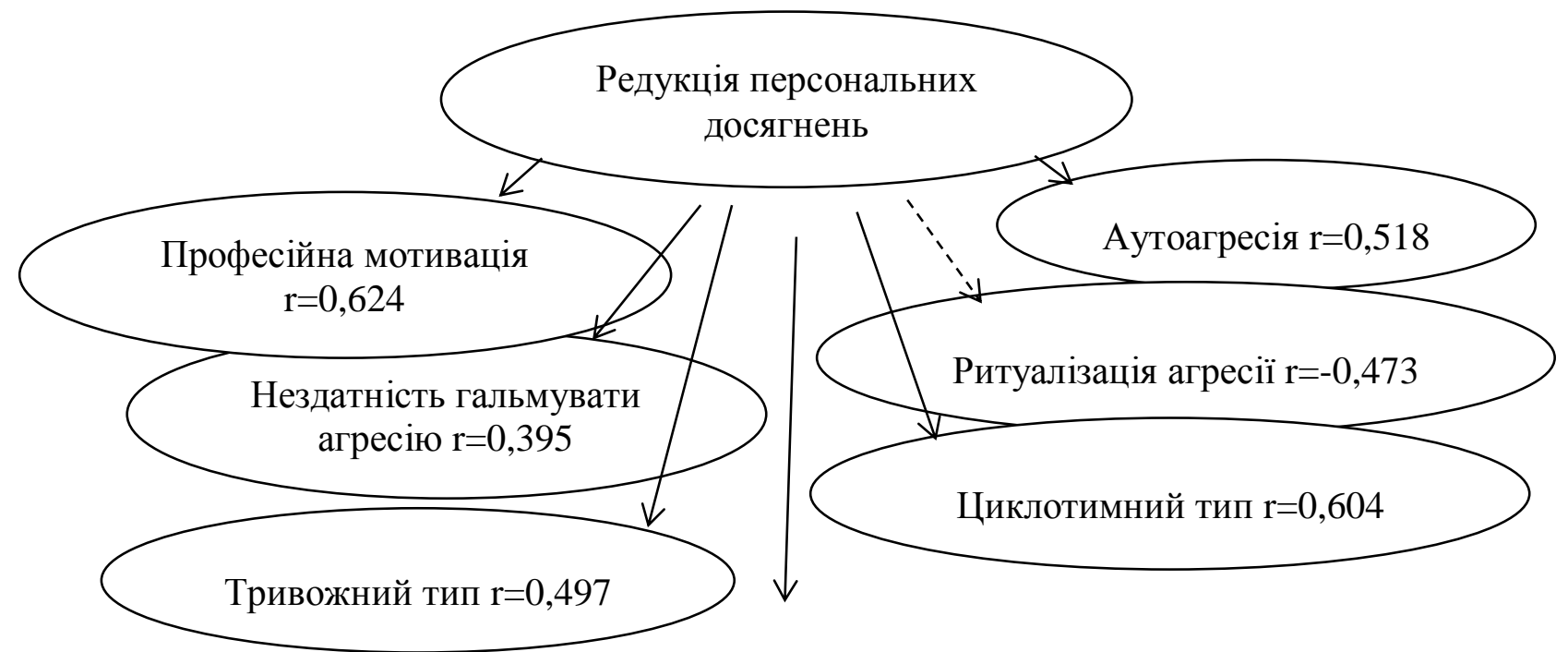


Рuc. 5. Кореляційна плеяда редукції персональних досягнень, професійної мотивації, аутоагресії, нездатності гальмувати агресію, ритуалізації агресії, тривожного та циклотимного типів акцентуації характеру та меланхолічного типу темпераменту особистості

У слідчих виявлено прямий позитивний кореляційний зв'язок між редукцією персональних досягнень та професійною мотивацією $(\mathrm{r}=0,624 ; \mathrm{p}=0,05)$; аутоагресією ( $\mathrm{r}=0,518$; $\mathrm{p}=0,01)$; нездатністю гальмувати агресію $(\mathrm{r}=0,395 ; \mathrm{p}=0,01)$; тривожним типом акцентуації $(\mathrm{r}=0,497 ; \mathrm{p}=0,05)$; циклотимним типом акцентуації $(\mathrm{r}=0,604 ; \mathrm{p}=0,05)$ та меланхолічним типом темпераменту особистості $(\mathrm{r}=0,319 ; \mathrm{p}=0,01)$. При високих показниках редукції персональних досягнень показники професійної мотивації, аутоагресії, нездатності гальмувати агресію, тривожного та циклотимного типів акцентуації були також високими. Існував негативний обернений кореляційний зв'язок поміж редукцією персональних досягнень та ритуалізацією агресії $(\mathrm{r}=-0,473 ; \mathrm{p}=0,01)$. При високих показниках редукції персональних досягнень показники ритуалізації агресії були низькими.

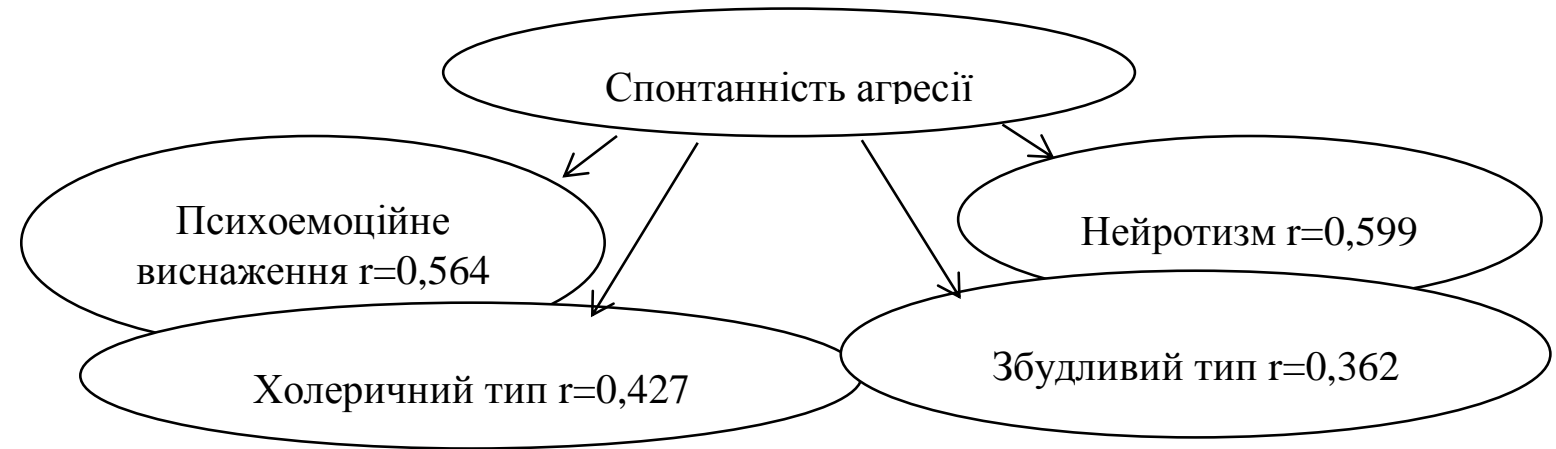

Puc. 6. Кореляційна плеяда спонтанності агресії, психоемоційного виснаження, нейротизму, збудливого типу акцентуації характеру та холеричного типу темпераменту особистості

У слідчих виявлено прямий позитивний кореляційний зв'язок між спонтанністю агресії та психоемоційним виснаженням $(\mathrm{r}=0,564 ; \mathrm{p}=0,05)$; нейротизмом $(\mathrm{r}=0,599 ; \mathrm{p}=0,01)$; збудливим типом акцентуації характеру $(\mathrm{r}=0,362 ; \mathrm{p}=0,01)$ та холеричним типом темпераменту особистості $(\mathrm{r}=0,427 ; \mathrm{p}=0,05)$. При високих показниках спонтанності агресії, показники психоемоційного виснаження, нейротизму, збудливого типу акцентуації характеру та холеричного типу темпераменту особистості були також високими.

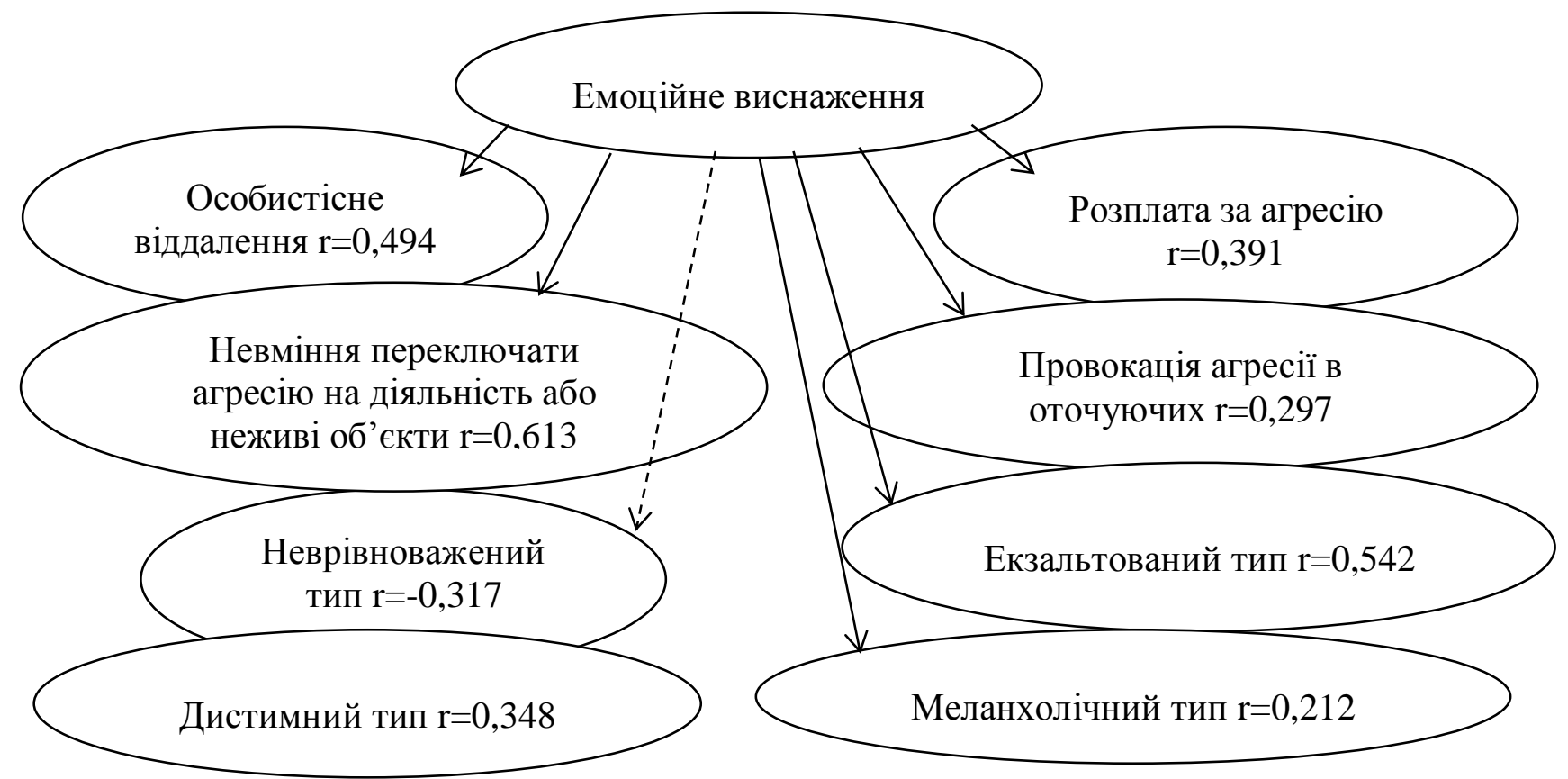


Puc. 7. Кореляційна плеяда емоційного виснаження, особистісного віддалення, розплати за агресію, невміння переключати агресію на діяльність або неживі об'єкти, провокації агресії в оточуючих, неврівноваженого, екзальтованого та дистимного типів акцентуації характеру та меланхолічного типу темпераменту особистості

У слідчих виявлено прямий позитивний кореляційний зв'язок між емоційним виснаженням та особистісним віддаленням ( $\mathrm{r}=0,494 ; \mathrm{p}=0,05)$; розплатою за агресію ( $\mathrm{r}=0,391$; $\mathrm{p}=0,01)$; невмінням переключати агресію на діяльність або неживі об'єкти (r=0,613; $\mathrm{p}=0,01)$; провокацією агресії в оточуючих (r=0,297; $\mathrm{p}=0,05)$; екзальтованим типом акцентуації характеру $(\mathrm{r}=0,542 ; \mathrm{p}=0,05)$; дистимним типом акцентуації характеру $(\mathrm{r}=0,348 ; \mathrm{p}=0,01)$ та меланхолічним типом темпераменту особистості $(\mathrm{r}=0,212 ; \mathrm{p}=0,05)$. При високих показниках емоційного виснаження показники особистісного віддалення, розплати за агресію, невміння переключати агресію на діяльність або неживі об'єкти, провокації агресії в навколишніх, екзальтованого та дистимного типів акцентуації характеру та меланхолічного типу темпераменту особистості були також високими. Існував негативний обернений кореляційний зв'язок між емоційним виснаженням та неврівноваженим типом акцентуації характеру $(\mathrm{r}=-0,317 ; \mathrm{p}=0,05)$. При високих показниках емоційного виснаження показники неврівноваженого типу акцентуації характеру були низькими.

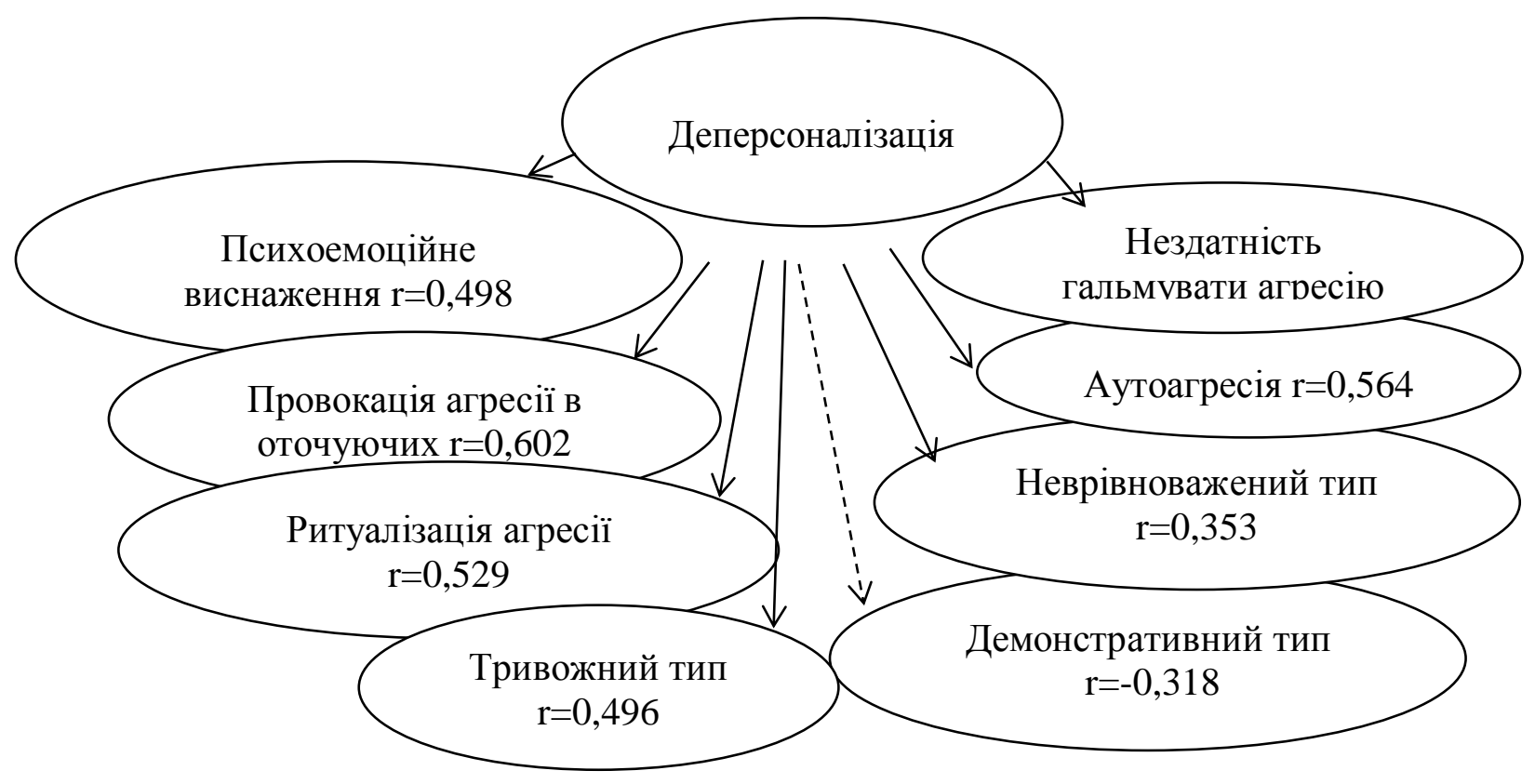

Puc. 8. Кореляційна плеяда деперсоналізації, психоемоційного виснаження, нездатності гальмувати агресію, провокації агресії в оточуючих, аутоагресії, ритуалізації агресії, неврівноваженого, тривожного та демонстративного типів акцентуації характеру

В оперуповноважених виявлено прямий позитивний кореляційний зв'язок між деперсоналізацією та психоемоційним виснаженням ( $\mathrm{r}=0,498 ; \mathrm{p}=0,05)$; нездатністю гальмувати агресію $(\mathrm{r}=0,273 ; \mathrm{p}=0,01)$; провокацією агресії в оточуючих $(\mathrm{r}=0,602 ; \mathrm{p}=0,05)$; аутоагресією $(\mathrm{r}=0,564 ; \mathrm{p}=0,01)$; ритуалізацією агресії $(\mathrm{r}=0,529 ; \mathrm{p}=0,05)$; неврівноваженим типом акцентуації характеру $(\mathrm{r}=0,353 ; \mathrm{p}=0,01)$ та тривожним типом акцентуації характеру $(\mathrm{r}=0,496 ; \mathrm{p}=0,05)$. При 
високих показниках деперсоналізації показники психоемоційного виснаження, нездатності гальмувати агресію, провокації агресії в оточуючих, аутоагресії, ритуалізації агресії, неврівноваженого та тривожного типів акцентуації характеру були також високими. Існував негативний обернений кореляційний зв'язок між деперсоналізацією та демонстративним типом акцентуації характеру ( $\mathrm{r}=-0,318 ; \mathrm{p}=0,01)$. При високих показниках деперсоналізації, показники демонстративного типу акцентуації характеру були низькими. 


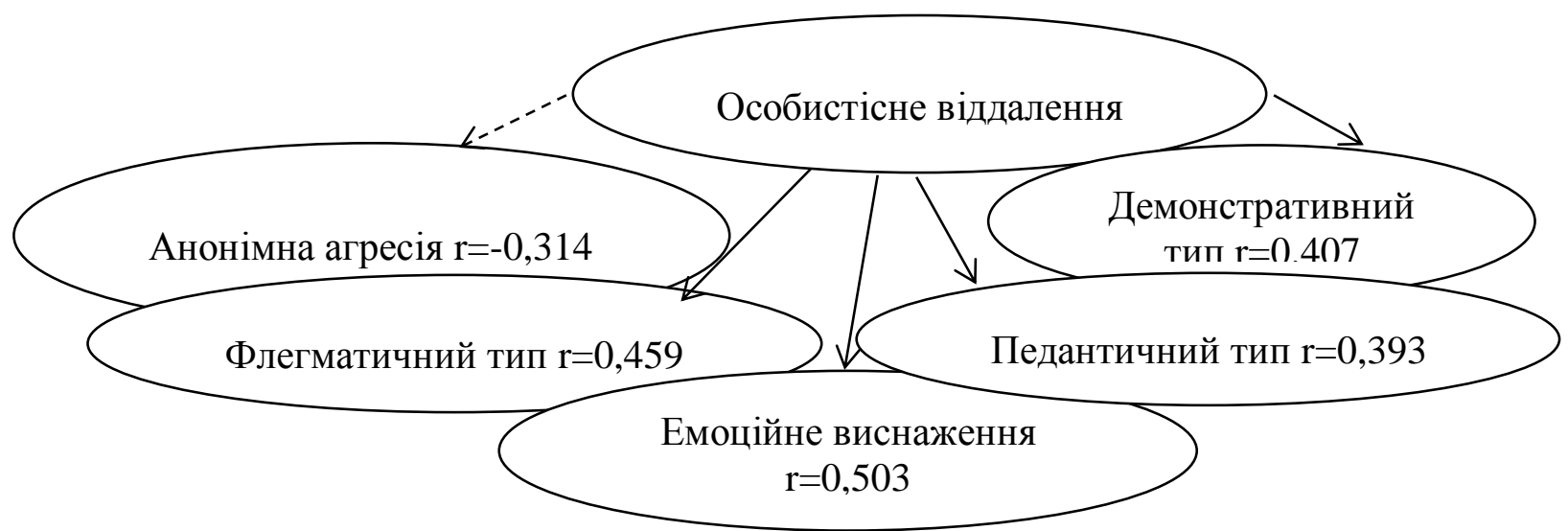

Puс. 9. Кореляційна плеяда особистісного віддалення, анонімної агресії, емоційного виснаження, демонстративного та педантичного типів акцентуації характеру та флегматичного типу темпераменту особистості

В оперуповноважених виявлено прямий позитивний кореляційний зв'язок між особистісним віддаленням та емоційним виснаженням $(\mathrm{r}=0,503 ; \mathrm{p}=0,05)$; демонстративним типом акцентуації характеру $(\mathrm{r}=0,407 ; \mathrm{p}=0,01)$; педантичним типом акцентуації характеру $(\mathrm{r}=0,393$; $\mathrm{p}=0,05)$ та флегматичним типом темпераменту особистості $(\mathrm{r}=0,459 ; \mathrm{p}=0,05)$. При високих показниках особистісного віддалення показники емоційного виснаження, демонстративного та педантичного типів акцентуації характеру були також високими. Існував негативний обернений кореляційний зв'язок між особистісним віддаленням та анонімною агресією $(\mathrm{r}=-0,314 ; \mathrm{p}=0,05)$. При високих показниках особистісного віддалення, показники анонімної агресії були низькими.

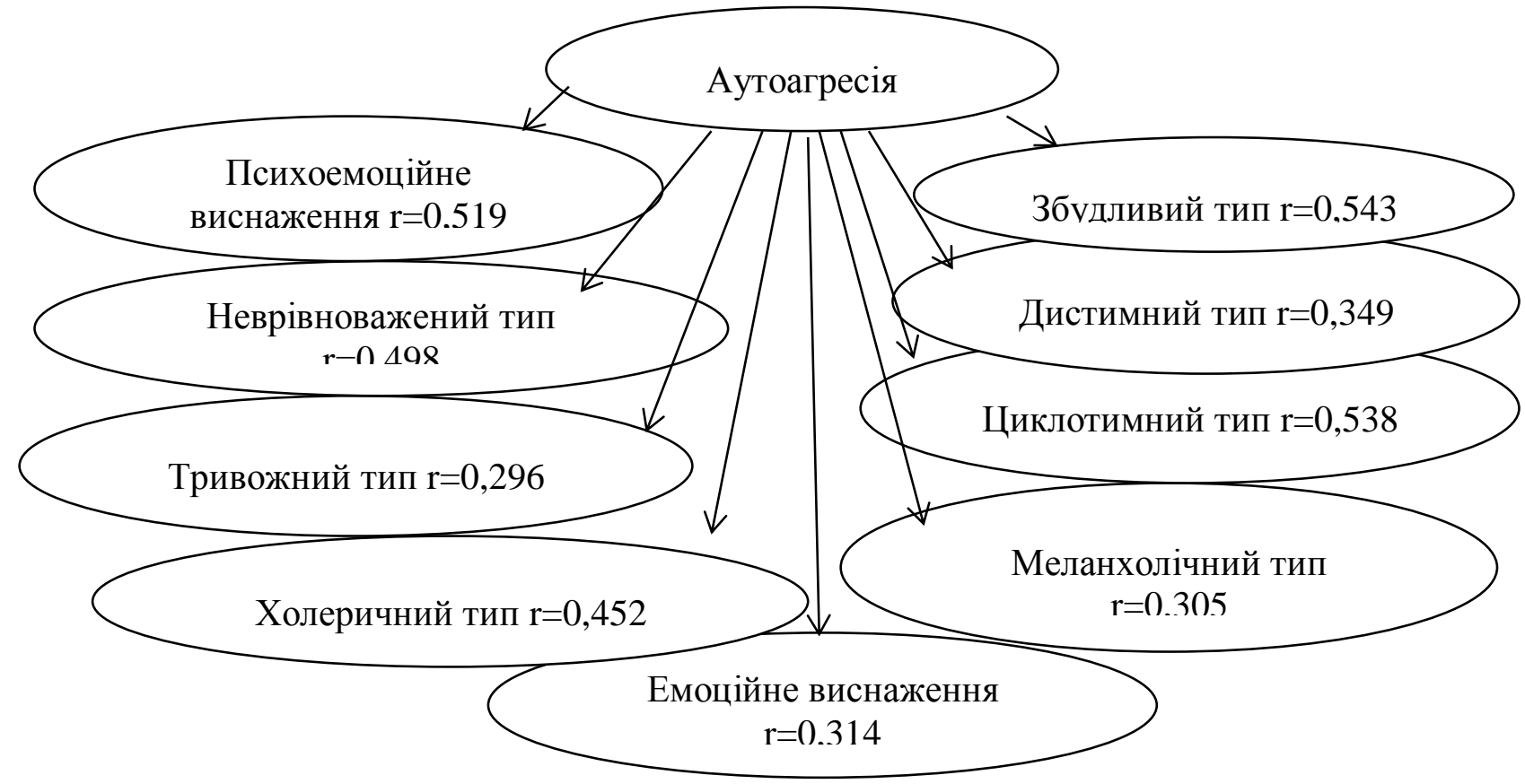

Рuc. 10. Кореляційна плеяда аутоагресії, психоемоційного виснаження, збудливого, неврівноваженого, дистимного, тривожного і циклотимного типів акцентуації характеру, холеричного та меланхолічного типів темпераменту особистості та емоційного виснаження

В оперуповноважених виявлено прямий позитивний кореляційний зв'язок між аутоагресією та психоемоційним виснаженням ( $\mathrm{r}=0,519 ; \mathrm{p}=0,05)$; збудливим типом акцентуації $(\mathrm{r}=0,543 ; \mathrm{p}=0,01)$; неврівноваженим типом акцентуації $(\mathrm{r}=0,498 ; \mathrm{p}=0,01)$; дистимним типом 
акцентуації ( $\mathrm{r}=0,349 ; \mathrm{p}=0,05)$; тривожним типом акцентуації характеру ( $\mathrm{r}=0,296 ; \mathrm{p}=0,01)$; циклотимним типом акцентуації характеру $(\mathrm{r}=0,538 ; \mathrm{p}=0,05)$; холеричним типом темпераменту особистості $(\mathrm{r}=0,452 ; \mathrm{p}=0,05)$; меланхолічним типом темпераменту особистості $(\mathrm{r}=0,305 ; \mathrm{p}=0,01)$ та емоційним виснаженням ( $\mathrm{r}=0,314 ; \mathrm{p}=0,05)$. При високих показниках аутоагресії показники психоемоційного виснаження, збудливого, неврівноваженого, дистимного та тривожного типів акцентуації характеру, холеричного та меланхолічного типів темпераменту особистості, емоційного виснаження були також високими.

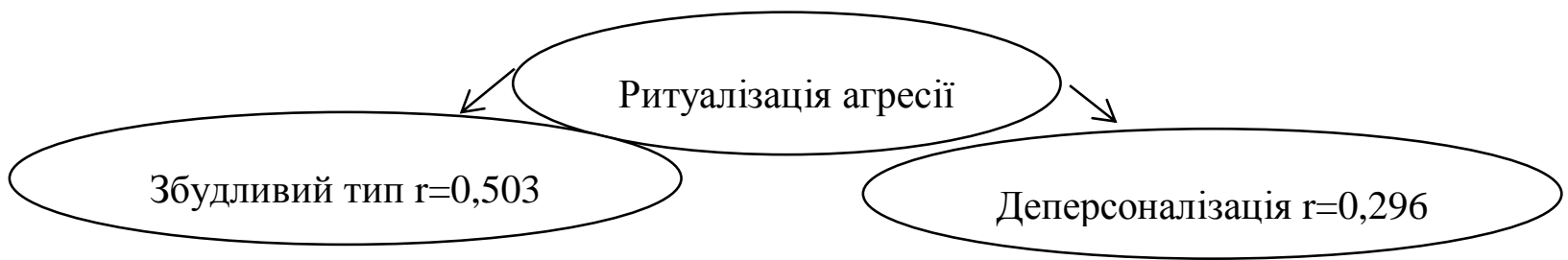

Рuc. 11. Кореляційна плеяда ритуалізації агресії, збудливого типу акцентуації характеру та деперсоналізації

В оперуповноважених виявлено прямий позитивний кореляційний зв'язок між ритуалізацією агресії та збудливим типом акцентуації характеру $(\mathrm{r}=0,503 ; \mathrm{p}=0,05)$ та деперсоналізацією (r=0,296; p=0,01). При високих показниках ритуалізації агресії показники збудливого типу акцентуації характеру та деперсоналізації були також високими.

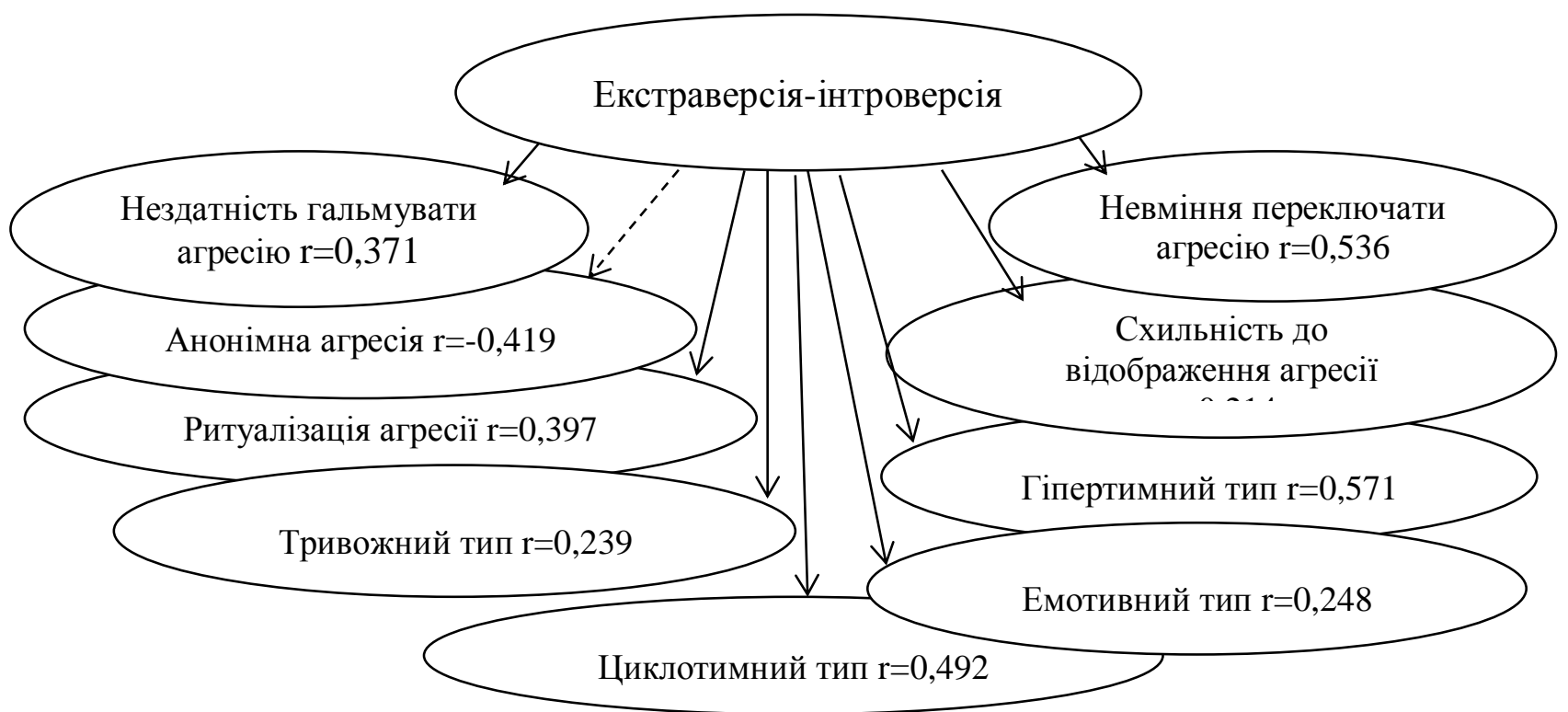

Puc. 12. Кореляційна плеяда екстраверсії-інтроверсії, нездатності гальмувати агресію, невміння переключати агресію на діяльність або неживі об'єкти, анонімної агресії, схильності до відображення агресії, ритуалізації агресії, гіпертимного, тривожного, емотивного та циклотимного типів акцентуації характеру

В оперуповноважених виявлено прямий позитивний кореляційний зв'язок між екстраверсією-інтроверсією та нездатністю гальмувати агресію $(\mathrm{r}=0,371 ; \mathrm{p}=0,05)$; невмінням переключати агресію на діяльність або неживі об'єкти (r=0,536; $\mathrm{p}=0,05)$; схильністю до відображення агресії $(\mathrm{r}=0,214 ; \mathrm{p}=0,05)$; ритуалізацією агресії $(\mathrm{r}=0,397 ; \mathrm{p}=0,01)$; гіпертимний типом акцентуації характеру $(\mathrm{r}=0,571 ; \mathrm{p}=0,05)$; тривожним типом акцентуації характеру $(\mathrm{r}=0,239 ; \mathrm{p}=0,01)$; емотивним типом акцентуації характеру $(\mathrm{r}=0,248 ; \mathrm{p}=0,05)$ та циклотимним типом акцентуації характеру $(r=0,492 ; \mathrm{p}=0,05)$. При високих показниках екстраверсії-інтроверсії 
показники нездатності гальмувати агресію, невміння переключати агресію на діяльність або неживі об'єкти, схильності до відображення агресії, ритуалізації агресії, гіпертимного, тривожного, емотивного та циклотимного типів акцентуації характеру були також високими. Існував негативний обернений кореляційний зв'язок між екстраверсією-інтроверсією та анонімною агресією (r=-0,419; $\mathrm{p}=0,05)$. При високих показниках екстраверсії-інтроверсії, показники анонімної агресії були низькими.

$\mathrm{B}$ оперуповноважених виявлено прямий позитивний кореляційний $3 \mathrm{~B}$ 'язок між невмінням переключати агресію на діяльність або неживі об'єкти та психоемоційним виснаженням $(\mathrm{r}=0,477 ; \mathrm{p}=0,05)$; неврівноваженим типом акцентуації характеру ( $\mathrm{r}=0,349$; $\mathrm{p}=0,01)$; збудливими типом акцентуації $(\mathrm{r}=0,501 ; \mathrm{p}=0,05)$; тривожним типом акцентуації характеру $(\mathrm{r}=0,318 ; \mathrm{p}=0,05)$; циклотимний типом акцентуації характеру $(\mathrm{r}=0,243 ; \mathrm{p}=0,01)$; нейротизмом $(\mathrm{r}=0,498 ; \mathrm{p}=0,05)$; холеричним типом темпераменту особистості $(\mathrm{r}=0,452 ; \mathrm{p}=0,05)$ та емоційним виснаженням $(\mathrm{r}=0,396 ; \mathrm{p}=0,01)$. При високих показниках невміння переключати агресію на діяльність або неживі об'єкти показники психоемоційного виснаження, неврівноваженого, збудливого, тривожного та циклотимного типів акцентуації характеру, нейротизму, холеричного типу темпераменту особистості та емоційного виснаження були також високими.

Висновок. Отже, у слідчих зв'язок наслідків професійного «вигорання» - психоемоційного виснаження, особистісного віддалення, редукції персональних досягнень 3 професійною мотивацією, спонтанністю агресії, екстраверсією-інтроверсією. В оперуповноважених психологічні особливості прояву професійного «вигорання» пов'язані з деперсоналізацією, екстраверсією-інтроверсією, невмінням переключати агресію на діяльність або неживі об'єкти, особистісним віддаленням, ритуалізацією агресії, аутоагресією та емоційним виснаженням.

Перспективу досліджень вбачаємо у розробці рекомендацій щодо кадрового відбору на вищевказані професії з урахуванням особистісних властивостей претендентів на посади та профілактиці й використанні корекційних методів 3 метою зниження рівня професійного «вигорання» серед працівників поліцейських підрозділів та інших ризиконебезпечних професій.

1. Водопьянова, Н. Е., Старченкова, Е. С. (2005). Синдром выгорания: диагностика и профилактика. СПб.: Изд-во «Питер».

2. Кісіль, 3. Р. (2015). Особистісні детермінанти розвитку професійної деформації працівників органів внутрішніх справ України. Науковий вісник Львівського державного університету внутрішніх справ. Серія психологічна, 2, 164-173.

3. Малкина-Пых, И. Г. (2009). Психологическая помощь в кризисных ситуаиіях. М.: Эксмо.

4. Медведев, В. С. (1999). Психология профессиональной деформации сотрудников органов внутренних дел. (Дис. док. психол. наук). Киев. ин-т внутр. дел при Нац. академ. внутр. дел Украины, Киев.

5. Синявська, О. Ю. (2005). Професійна етика як чинник протидії професійній деформації працівників органів внутрішніх справ. Право і безпека, 4 (1), 96-99.

\section{REFERENCES}

1. Vodopyanova, N. Ye., Starchenkova, Ye. S. (2005). Sindrom vyhoraniya: diahnostika i profilaktika [Burnout syndrome: diagnosis and prevention]. $\mathrm{SPb}$.: Izd-vo «Piter». (rus).

2. Kisil, Z. R. (2015). Osobystisni determinanty rozvytku profesiynoyi deformatsiyi pratsivnykiv orhaniv vnutrishnikh sprav Ukrayiny. [Personality determinants of professional deformation of employees of the bodies of internal affairs of Ukraine]. Naukovyy visnyk L'vivs'koho derzhavnoho universytetu vnutrishnikh sprav. Seriya psykholohichna [Scientific herald of Lviv State University of Internal Affairs. The Psychological series], 2, 164-173. (ukr).

3. Malkina-Pykh, I. H. (2009). Psikholohicheskaya pomoshch v krizisnykh situatsíyakh [Psychological assistance in crisis situations]. M: Eksmo. (rus).

4. Medvedev, V. S. (1999). Psikholohiya professionalnoy deformatsii sotrudnikov organov vnutrennikh del [Psychology of professional deformation of internal affairs officers]. (Dis. dok. psikhol. nauk). Kyev. in-t vnutr. del pri Nats. akadem. vnutr. del Ukrainy, Kyev. (rus).

5. Synyavska, O. Yu. (2005). Profesiyna etyka yak chynnyk protydiyi profesiyniy deformatsiyi pratsivnykiv orhaniv vnutrishnikh sprav [Professional ethics as a factor in counteracting professional deformation of employees of the bodies of internal affairs]. Pravo i bezpeka [Right and safety], 4 (1), 96-99. (ukr). 



\section{Zoriana Kovalchuk \\ THE INFLUENCE OF PERSONAL PROPERTIES ON THE FORMATION OF PROFESSIONAL DEFORMATION OF EPLOYEES OF RISKY PROFESSIONS}

In the article the author substantiates theoretically and proves empirically the influence of personal qualities on the formation of professional deformation of employees of risky professions, particularly investigators and detectives of the National Police of Ukraine. It is ndicated that professionally important qualities of a specialist are developed during a long professional activity, and at the same time the employee acquires some other qualities that deform the person. Thus, the development of various professional destructions takes place during professional formation. In order to detect the deformation processes of law enforcement officers of different units and determine the ways of their prevention the author conducted an empirical study using a number of psychodiagnostic techniques, such as: "Definition of mental burnout" (O. Rukavishnikov), "Definition of integral forms of communicative aggressiveness" (V. Boyko), "Study of the integral accentuations of a personality" (K. Leonhard, modification of S. Shmyshek), "Personality questionnaire" (G. Eysenk), Questionnaire "Professional burnout" (K. Maslach, S. Jackson, adapted by N. Vodopyanova). Correlation analysis showed that there was a professional "burnout" in the investigators associated with psychoemotional exhaustion, personal distance, professional motivation, spontaneity of aggression, extraversion-introversion, reduction of personal achievements. Detectives' professional burnout is associated with depersonalization, extraversion-introversion, inability to switch aggression over activity or inanimate objects, personal distance, ritualization of aggression, auto-aggression and emotional exhaustion. The author expects the prospect of research in developing recommendations on personnel selection for the above-mentioned professions, taking into consideration the personal qualities of applicants for positions and the prevention and use of corrective methods aiming to reduce the level of professional burnout among police officers and other risky professions.

Keywords: professional deformation, professional burnout, risky professions, investigators, detectives, emotional exhaustion. 